\title{
Islam and COVID-19: Understanding the ethics of decision making during a pandemic
}

\section{Mehrunisha Suleman ${ }^{1}$, Aziz Sheikh ${ }^{2}$}

${ }^{1}$ Center of Islamic Studies, University of Cambridge, Cambridge, UK

${ }^{2}$ Usher Institute, The University of Edinburgh, Edinburgh, UK

T The COVID-19 pandemic has brought into sharp focus how a global emergency has impacted all aspects of life. As countries emerge from the first wave of the COVID-19 pandemic, meaningful changes to coordination in global health and religious leadership are necessary to ensure safety and health for all, especially the most vulnerable [1]. Analysing the experience of Muslims across the globe to understand the interaction between governmental, health authorities and religious leadership reveals that these interactions and responses differ and require deep contextual and religious examination. Examining responses to the COVID-19 pandemic reveal both opportunities and challenges for working with faith communities. For example, in the UK the response of Muslim organisations has been to support national and devolved governmental positions including the suspension of acts of communal worship [2]. In stark contrast in Muslim majority countries like Pakistan, religious authorities have publicly challenged and reversed similar decisions [3,4]. How are such difference to be understood? And what are the implications for subsequent waves of the COVID-19 or future pandemics?

Islam as a faith tradition and "way of life" has long encouraged the pursuit of science, medicine and biotechnology as solutions to human suffering.
Islam as a faith tradition and 'way of life' has long encouraged the pursuit of science, medicine and biotechnology as solutions to human suffering [5]. However, very little analysis has been done on the impact of Islam, as a normative tradition and a structure of authority, in response to the COVID-19 pandemic. Here we argue that the religious tradition itself offers recognisable solutions through values such as 'protection of life' and public health principles like quarantine to help curtail the spread of infectious diseases. We will also show that, in addition to this religious framework there is a lived religious practice [6] by which we mean how the tradition is understood and practiced by ordinary Muslims.. Understanding the interplay of the religious tradition and religious authority is critical for global health bodies like the World Health Organization (WHO) to work effectively with governments and faith-based organisations to ensure understanding and uptake of evidence-based public health interventions [7].

\section{ISLAMIC VALUES RESPONSIVE TO A GLOBAL PANDEMIC}

The Islamic tradition is replete with teachings from the Prophet Muhammad about protecting individuals and communities, including in the event of an outbreak or pandemic. For example, a well-known tradition of the Prophet (Hadith) states:

"If you hear of an outbreak or plague in a land, do not enter it; but if the plague breaks out in a place while you are in it, do not leave that place" [8]

More fundamentally, understanding the objectives of the Shariah (Islamic law) [9] can be helpful in clarifying what an appropriate Islamic response ought to be (see Box 1). The elucidation of these objectives comes 
Box 1. Objectives of the Shariah (Maqasid al Shariah).

They include preservation of:

1. Faith

2. Life

3. Intellect

4. Progeny

5. Property/wealth

through scholarly analysis of the Qur'an and Hadith. The aforementioned tradition, for example, enables the extraction of the objective of 'protection of life' underlining the status and value of life in the Shariah.

\section{MAQASID SHARIAH: BALANCING AND PRIORITISING COMPETING VALUES}

These objectives, however, also include 'protection of faith' and 'protection of wealth'. Ordinarily synergistic, the pandemic is forcing a fundamental recalibration of how such values are understood, balanced and even prioritised. The variation in global responses to the pandemic in both Muslim majority and minority settings may be due to distinctiveness in how these objectives are ranked.

\section{VARIATION IN HOW THESE COMPETING VALUES ARE UNDERSTOOD AND OPERATIONALISED}

For example, in the UK there was a concerted effort to curtail spread of disease and prioritise "protection of life' by the closure of places of worship and an emphasis on families not observing the usual communitarian rituals of Ramadhan, including collective prayers, coming together for breaking of the fast at sunset, and the celebration of Eid. Such responses are juxtaposed against for example, Pakistan, where the religious establishment maintained that believers should remain steadfast in attending congregational prayers in mosques. Such advice was contrary to that being offered by the Pakistani government. However, the government subsequently amended its advice in response to religious pressures despite consistent advice from the Pakistan Medical Association to prohibit such gatherings, which would render it impossible to maintain physical distancing [10]. Competing advice and observing how religious authorities may usurp both governmental and medical structures in the contexts of a pandemic is poorly understood. The religious authorities in such contexts sought to 'protect faith' and also may have worried about the impact of suspending religious activities on mental and physical health, particularly in the month of Ramadhan. There may furthermore have been concerns about maintaining the integrity of faith institutions, particularly in the context of high morbidity and mortality.

\section{The tradition offers recognisable solu- tions through values such as "protection of life' and public health principles like quarantine to help curtail the spread of infectious diseases.}

The variation in the understanding of such values and how they are operationalised needs to be further examined. Partaking in religious activities can have benefits for physical and mental health. In the face of considerable insecurity and a lack of control over their immediate and long-term future, many Muslims may see their faith as a much needed stabilising force. Some authors have gone so far to suggest that commitments, practices and meaning making offered by religious faiths could make an important difference in how some cope and manage to come through this pandemic [11]. It is unclear, however, whether the decisionmaking by religious authorities during the COVID-19 pandemic in Pakistan was driven by such concerns or whether the context of an emergency and subsequent uncertainty presented a lacuna of leadership and authority that different social elements were keen to exploit.

\section{IMPLICATIONS FOR SUBSEQUENT WAVES AND FUTURE PANDEMICS}

Evidence shows that religion is a social determinant of public health in how it institutionally and otherwise interacts with other influential determinants such as politics and economics [12]. We are seeing through this pandemic how religion has the scope to support and inform evidence-based ethical decision making within global health. There have been heroic efforts to adapt religious activities including online sermons, prayers, offers of financial help, distribution of food and other resources through mosque networks and volunteers. However, such involvement will need to be carefully negotiated to prevent potential unintended consequences including religious institutions and authorities being taken as the main public health authority [13]. Such work will require a careful understanding of the different actors, the fault lines of influence and levels of power operating in context of political, health and religious leadership. 


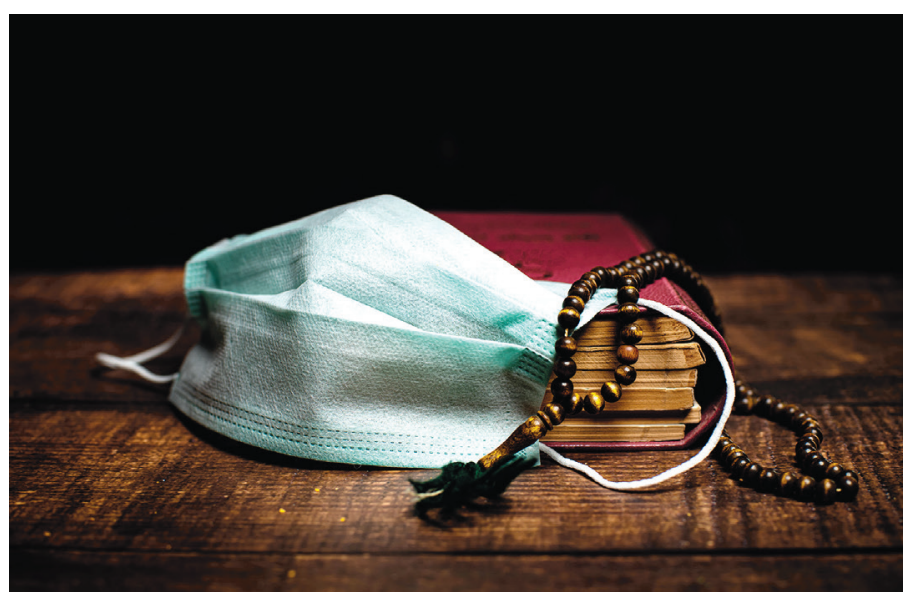

Photo: Holy Al Quran, prayer beads and protective mask on wooden table (via Getty Images).
What is also critical to highlight is that responses to the pandemic by religious authorities, through the deliberation of Islamic values, is not limited to religious duties. For example, although it is understood that physical distancing and quarantining can limit the spread of disease thereby 'protecting life', this is but one half of the negotiation. The ethical tension presented by the pandemic is that prioritisation of values like 'protection of life' and 'protection of wealth' need countermeasures to lockdown, including returning to work and re-starting the economy. Just as religion can impact all facets of life, economic and social factors impact interpretation of religious norms and values. The differing responses seen between countries and different religious authorities may also suggest that the prioritisation of values might need to be different at different times in a pandemic. For example, in the early phase emphasis may need to be placed on 'protection of life', and in the medium to later phases other values such as 'protection of faith' through re-opening or re-establishing religious institutions, and 'protection of wealth' through supporting the economy may need to be prioritised. Constant reassessment of values and priorities as the pandemic evolves will enable a more responsive approach. This analysis also reveals that the Maqasid al Shariah framework is a dynamic ethical framework one that can be adapted to changing circumstances. Such resources mean that religious authorities have the scope of working in concert with public health bodies and other agencies to ensure a more holistic return from lockdown, one that imbibes economic, social and spiritual recovery.

The pandemic has put a spotlight on how the role of religion, religious knowledge, language and authority in the context of global health is poorly understood. Research is needed to understand the different sources and types of authority beyond the well recognised political and public health institutions in the context of public health emergencies. The current context has led to radical changes in the way people are being informed of and understand risk and subsequently the measures that are being deployed in response to this global emergency [7]. The wave of uncertainty, which has touched every part of our lives and every part of society, means that more than ever we need responsible and responsive leadership that we can rely on to help us build back a more resilient global architecture for health, wealth and well-being. For many across the world, dealing with uncertainty involves a deeper reliance on religious beliefs, rituals and faith communities.

Pandemics are likely to recur and if we are to successfully implement measures to curtail spread it is critical to be able to locate and successfully liaise with what the public considers trusted people and trusted spaces. Furthermore, systematic analyses of teachings from the Islamic tradition are likely to offer resources for ethically evaluating and managing global health challenges, such as pandemics. Such analyses will, we hope, provide organisations like the WHO with an evidence base to more effectively engage with Muslim majority countries and faith-based organisations. Such engagement ought to be long-term, including scenario planning, to inform discussions and debates pertaining to the ongoing response to COVID-19 and future pandemics.

Authorship contributions: MS co-conceived the idea for this paper and prepared several drafts of the manuscript. AS co-conceived the idea for this paper and commented critically on several drafts of the manuscript.

Competing interests: AS is a member of the Scottish Government's Chief Medical Officer's COVID-19 Advisory Group, a member of the UK Government's New and Emerging Respiratory Virus Threats (NERVTAG) Risk Stratification Subgroup and an adviser to WHO. The authors have completed the ICMJE COI form (available upon request from the corresponding author), and declare no further conflicts of interest. 
1 World Health Organization. Practical considerations and recommendations for religious leaders and faith-based communities in the context of COVID-19: interim guidance, 7 April 2020 (No. WHO/2019-nCoV/Religious_Leaders/2020.1). Geneva: World Health Organization; 2020.

2 The British Board of Scholars \& Imams. UK Community Briefing paper for Imams, Mosques, and Madrasas for the Coronavirus Pandemic (BBSIG-02); 2020.

3 Butt G, Hussain I. Sociocultural and Religious Factors Associated with Varied Response in General Public in Pakistan Regarding COVID-19. Annals of King Edward Medical University. 2020;26:104-6.

4 Ghadyani M, Hussain H, Odeh W, Wood P. Responses to the COVID-19 Pandemic in Syria, Iran and Pakistan. Abdou FilaliAnsary Occasional Paper Series. Issue 2. Available: https://ecommons.aku.edu/cgi/viewcontent.cgi?article=1001\&context=uk_ ismc_series_ops. Accessed: 17 July 2020.

5 Inhorn MC. Conclusion. In: Brockopp JE, \& Eich T. Muslim medical ethics: from theory to practice. Colombia, SC: University of South Carolina Press; 2008.

6 Suleman M. Islam and Biomedical Research Ethics. Routledge. New York. 2020.

7 Bavel JJ, Baicker K, Boggio PS, Capraro V, Cichocka A, Cikara M, et al. Using social and behavioural science to support COVID-19 pandemic response. Nat Hum Behav. 2020;4:460-71. Medline:32355299 doi:10.1038/s41562-020-0884-z

8 Sahih Bukhari Book 76, Hadith 43: The Prophet Said: "If you hear of an outbreak or plague in a land, do not enter it; but if the plague breaks out in a place while you are in it, do not leave that place."

9 Kamali MH. Maqasid Al-Shariah made simple. Cambridge: IIIT; 2008.

10 CNN. In Pakistan's fight against Covid-19, religion might not be helping Available: https://edition.cnn.com/2020/04/25/opinions/pakistan-coronavirus-lockdown-intl-hnk/index.html. Accessed: 3 July 2020.

11 Hart CW, Koenig HG. Religion and Health During the COVID-19 Pandemic. J Relig Health. 2020;59:1141-3. Medline:32415424 doi:10.1007/s10943-020-01042-3

12 Idler EL, editor. Religion as a social determinant of public health. New York, NY: Oxford University Press; 2004.

13 Jabbour S, Fouad FM. Religion-based tobacco control interventions: how should WHO proceed? Bull World Health Organ. 2004;82:923-7. Medline:15654406

\section{Correspondence to:}

Dr Mehrunisha Suleman

Centre of Islamic Studies

University of Cambridge

Faculty of Asian and Middle Eastern Studies

Sidgwick Avenue

Cambridge, CB3 9DA

UK

ms520@cam.ac.uk 